\title{
Çocuğa Yönelik Şiddete Duyarlık Ölçeği Geliştirme Çalışması
}

\author{
Arzu Özyürek*
}

Karabük Üniversitesi, Să̆lık Bilimleri Fakültesi, Karabük.

\begin{abstract}
$\ddot{O} z$
Şiddet davranışlarının gelişimi ve bireylerin şiddete yönelik algılarında bireysel, çevresel veya kültürel çok sayıda faktör etkili olmaktadır. Özellikle çocuğa yönelik şiddet, tüm dünyada üzerinde önemle durulan bir konudur. Alan yazında, konuyla ilgili çalısmalarda genellikle anket formlarından yararlanıldığı görülmektedir. Bu nedenle bu çalışmada, yetişkinlerin çocuğa yönelik şiddete duyarlıkların belirlemeye yönelik bir ölçme aracı geliştirmek amaçlanmıştır. Çalışma grubunu 202 lisans öğrencisi oluşturmuştur. Ölçek maddelerinin kapsam geçerliği uzman görüşleriyle sağlanmıştır. Yapı geçerliğinin belirlenmesi amacıyla Açımlayıcı Faktör Analizi (AFA) ve Cronbach Alfa güvenirlik katsayısından yararlanılmıştır. Ölçeğin 19 maddelik tek boyuttan oluştuğu belirlenmiştir. Ölçeğin ölçüt geçerliği için yaş ve cinsiyet dış ölçüt alınarak analiz yapılmıştır. Sonuç olarak; yaşın çocuğa yönelik şiddete duyarlık üzerinde anlamlı etkisi olmadığı, cinsiyetin ise etkili olduğ u belirlenmiştir. Ölçeğin Cronbach Alpha iç tutarlık katsayısı 0,82 olarak hesaplanmış ve Çocuğa Yönelik Şiddete Duyarlık Ölçeğinin yetişkinlerin çocuğa yönelik şiddete duyarlığını ayırt edebileceği sonucuna varılmıştır.
\end{abstract}

Anahtar Kelimeler: Şiddet, Şiddete Duyarlık, Çocuğa Yönelik Şiddet, Geçerlik, Güvenirlik.

\section{A Study on Development of a Scale on Violence Sensitivity towards Children}

\section{Abstract}

Several individual, environmental or cultural factors are influential in development of violent behavior and in the perceptions of individuals towards violence. Especially, the issue of violence against children is an issue that has been emphasized globally. In the literature, it was observed that survey forms are generally used in related studies. The present study aimed to develop a measurement tool to determine the sensitivities of adults on violence against children. The study group included 202 undergraduate students. Scale content validity was established with expert opinion. Exploratory Factor Analysis (EFA) and Cronbach Alpha reliability coefficients were used to determine the construct validity. It was determined that the scale included a single 19-item dimension. Scale criterion validity was analyzed with age and gender as external criteria. As a result, it was determined that age did not have a significant effect on sensitivity on the violence against children, while gender had a significant impact on the same. The Cronbach Alpha internal consistency coefficient of the scale was calculated as 0.82 and the Violence Sensitivity towards Children Scale could differentiate on sensitivity of adults for violence against children.

Keywords: Violence, Violence Sensitivity, Violence against Children, Validity, Reliability.

\section{Gíriş}

Çocuklara ve gençlere yönelik şiddet, önemli bir halk sağlığı ve insan hakları konularından biridir. Çocuklara yönelik şiddet verileri yetersiz olsa da özellikle düşük veya orta sosyo-ekonomik düzeydeki ülkelerde, şiddet risk faktörleri ve koruyucu faktörler üzerinde çalışılmaktadır (Devries vd, 2016: 159). Aile içinde zorlama, cezalandırma, aşağılama, sevgisiz bırakma gibi öfke ve gerginliği boşaltmak amacıyla anne-baba tarafından çocuklara yöneltilen fiziksel, cinsel, duygusal şiddet ve ihmal 
niteliğindeki olumsuz her türlü davranış şiddet olarak tanımlanabilir (Ayan, 2007: 32). Saldırganlık ve şiddet davranışları, bireylerin iletişimini bozan, her iki tarafa da rahatsızlık veren, kontrol edilemeyen duygusal tepkilerdir (Özaltın, 2001: 108). Çocukların şiddete maruz kalmaları, gelişimlerini olumsuz olarak etkilemekte, özellikle en güvenli olması gereken okul ve ev ortamı başta olmak üzere, çeşitli ortamlarda fiziksel, sözel, ilişkisel ve cinsel şiddete maruz kalabildikleri görülmektedir (Çetinkaya Yıldız ve Hatipoğlu Sümer, 2010: 632).

Saldırganlık ve şiddet davranışlarının nedenleri tam olarak tanımlanamasa da çeşitli şekillerde açıklanmaya çalışılmıştır. Freud, saldırgan davranışların nedeninin libidinal dürtülerin doyurulmasının engellenmesine bir tepki olduğunu, ölüm içgüdüsünün diğer insanlara yönlendirilmesinden kaynaklandığını ileri sürmüştür. Bandura'nın sosyal öğrenme kuramına göre, insanlar geçmiş deneyimleri, saldırgan tepkilerinin takdir edilmesi veya sosyal çevre tarafından teşvik edilmesiyle birbirlerine karşı saldırgan davranışlar göstermektedirler. Ayrıca çoğu çalışmada, şiddetli fiziksel istismara uğramış insanlarda oluşan sinirsel bozulmanın, biyolojik olarak şiddete yatkınlığa neden olduğunu ortaya konmuştur (Akt.: Başbakanlık Aile Araştırma Kurumu, 1998: 10-12). Şiddet davranışlarının gelişiminde kişisel, sosyal ve kültürel etmenlerin rol oynadığı söylenebilir. Kişilerin madde kullanımı, zihinsel bozukluklar, kafa travmaları ve kişilik bozukluklarının şiddet davranışlarıyla yakından ilişkili olduğu belirlenmiştir (Volavka, 1999: 307). Fromm'a göre ise ölüm sevgisi, hastalıklı narsisizm ve birlikte yaşayan insanlar arasındaki kandaşla cinsel ilişki saplantısı eğilimleri insanlar tarafından değişik biçimlerde kullanılarak şiddete dönüşmektedir (Ayan, 2007: 34).

Saldırganlık gösteren bireyler, bunu genellikle aile üyeleri üzerinde gerçekleştirirken, gençlik dönemindeki erkekler tanımadıkları insanlara karşı saldırganlık sergileyebilmektedirler (Başbakanlık Aile Araştırma Kurumu, 1998: 9). Şiddet davranışları, aile içinde veya toplumun diğer kesimlerinde şiddete tanık olarak öğrenilebilmektedir. Gürültü, kalabalık ve alkol gibi çevresel etkenlerle ortaya çıkan şiddet davranışları, çevrenin verdiği tepkilere göre şekillenmektedir (Sezer, 2008: 6). Çocuk yetiştirmedeki geleneksel değerlerin rolü, ekonomik güçlükler, anne-baba yoksunluğu, medyada yer alan haberler veya programlar da şiddet davranışlarının ortaya çıkmasında farklı düzeyde etkili olabilmektedir (Özaltın, 2001: 109). Ekolojik etkenlerle, bireyin şiddete yönelik davranışları arasında da bir ilişki vardır. İnsanın ruhsal yapısı ve yaşantısı, toplum içinde gelişip oluşmaktadır. Kültürel değerler tarafından meydana getirilen üst benlik ne kadar bastırıcı, katı ve sert olursa, saldırgan davranışların ortaya çıkması da o kadar kolay ve şiddetli olmaktadır (Ayan, 2007: 43).

Alanyazında, okul öncesi dönemden itibaren şiddet olgusunu inceleyen bazı çalışmalarda, geçerlik ve güvenirliği yapılan standart bir ölçme aracı yerine araştırmacılar tarafından geliştirilen anket formlarından yararlanıldığı (Alkan, 2007; Ayan, 2007; Çobanoğlu, Şentürk ve Kıran, 2008; Deveci, Karadağ ve Y1lmaz, 2008; EARGED, 2008; Sever ve Cinoğlu, 2010; Elmalı, Kaya Erten, Zincir, Özen ve Balc1, 2011; Aydoğan ve Özyürek, 2013; Battaloğlu-İnanç, Çiftçi ve Değer, 2013; Tezel Şahin ve Özyürek, 2014) görülmüştür. Şiddetle ilgili olarak flört ve yakın ilişkilerde şiddet 
(Akın, Gülşen, Aşut ve Akça, 2012; Yumuşak ve Şahin, 2014) işyerinde psikolojik şiddet (Yaman, 2009; Yaman, 2012), endişe ve şiddet (Tunay ve Soygüt, 2009), okulda şiddet ve akran şiddeti (Can, 2007; Ogelman, Körükçü, Sarıkaya, Güngör ve Ersan, 2015; Savaş, İnandı, Peker ve Alışkın, 2015), kadına yönelik şiddet (Işık ve SakallıUğurlu, 2009; Koştu ve Toraman, 2016; Tuz, Öksüz ve Tekiner, 2015), aile içi şiddet (Sezer, 2008; Şahin ve Dişsiz, 2009) alanında ölçme araçları geliştirildiği veya Türkçeye uyarlandığı gözlenmiştir. Farklı isimlerde olup alt boyutlarında şiddetin ele alındığ 1 veya özellik olarak sosyal davranışları kapsayıp şiddet konusuna vurgu yapılan ölçekler de mevcuttur (Ekşi, Erkilet, Otrar, Durmuş, Erdoğan vd, 2010; Kurnaz ve Kapçı, 2013). Ancak yetişkinlerin çocuğa yönelik şiddet algısı veya duyarlığını belirlemeye yönelik bir ölçme aracına rastlanmamıştır. Duyarlık, zayıf bir etkiye karşı tepki gösterebilme yeteneği olarak tanımlanmaktadır (www.tdk.gov.tr, 2017). Çocuğa yönelik şiddete duyarlı olmak, bu tür olaylara tepki gösterebilmenin de bir işareti olarak kabul edilebilir. Şiddet davranışlarının gelişiminde olduğu gibi bireysel, çevresel veya kültürel birçok faktörün, bireylerin şiddete yönelik algılarını ve duyarlığını etkilediği açıktır. Şiddet kavramı ve eylemlerinin yorumu, olayların algılanışına göre değişebilir. Oysa saldırganlık ya da şiddet eğiliminin fark edilmesi, onun kontrol altına alınmasında önemli bir aşamadır (Özaltın, 2001: 111).

Alan yazın incelendiğinde şiddet olgusunun şiddetin tanımı, boyutları, nedenleri, özellikleri ve önlenmesine kadar birçok başlık altında incelendiği; şiddete maruz kalma, şiddet durumunda yapılanlar, şiddeti destekleme, şiddeti kabul etme (Şenol ve Yıldız, 2013), şiddeti olağanlaştırma, şiddeti genelleştirme, şiddeti nedenselleştirme, şiddeti saklama (Şahin ve Dişsiz, 2009) gibi alt başlıklar olarak ele alındığı görülmüştür. Şiddet algısı, farkındalığı ve duyarlığının şiddetin tanımı, genelleştirilmesi, kabul edilmesi, neden ve sonuçlarının bilinmesi, önlenmesi gibi faktörlerle ilgili olduğu düşünülebilir. Tanımlama; bir kavram ya da nesnenin sınırlanması, belirlenmesi, bir sözcüğün anlamının belirtilmesi, genelleştirme; tek tek ya da özel durumlardan genel bir önermenin çıkarılması, neden; bir olayı oluşturan koşul, kabul; bir durumu onaylama, sonuç; öncüllerden çıkarılan önerme, önleme ise; bir durumu önceden kestirerek gereken yanitı önceden verme olarak tanımlanabilir (www.tdk.gov.tr, 2017). Yetişkinlerin çocuğa yönelik şiddete duyarlıklarının belirlenmesinin, şiddeti önlenme çalışmalarına 1şık tutacağından hareketle, bu çalışmada çocuğa yönelik şiddete duyarlığı belirleyebilecek bir ölçme aracı geliştirilmesi, geçerlik ve güvenirlik çalışmaları yapılarak alana katkı sağlanması amaçlanmıştır.

\section{YÖNTEM}

Yetişkin bireylerin çocuğa yönelik şiddete duyarlıklarının belirlenmesininin amaçlandığ 1 ölçeğin geliştirilmesinde, aşağıdaki basamaklar izlenmiştir:

-Kapsam geçerliği aşamasında; şiddet konusuyla ilgili alanyazın taranmış, mevcut ölçekler incelenmiş, çocuğa yönelik şiddet algısıyla ilgili olarak çocuğa yönelik şiddetin tanımı (5 madde), şiddetin normalleştirilmesi (6 madde), şiddetin nedeni (10 madde), şiddeti kabul etme (8 madde), şiddetin sonuçları (5 madde) ve şiddeti önlemeyi (7 
madde) içeren 41 maddelik madde havuzu oluşturulmuştur. Maddelerin amaca uygunluğu, açık ve anlaşılırlığı, kapsamı ve bilimselliği gibi konularda yedi öğretim üyesi alan uzmanının görüşü alınmıştır. Öğretim üyelerinden gelen geri bildirimler sonucunda kapsam dışı olması nedeniyle 8 madde çıkarılmış, 2 madde düzeltilmiştir. $\mathrm{Bu}$ yolla 33 maddelik bir taslak form oluşturulmuştur. Oluşturulan taslak formun giriş kısmına uygulama yönergesi yazılmıştır. Ölçme-değerlendirme uzman görüşü alınıp üçlü likert tipine uygun olarak düzenlenmiş ve derecelendirme "Katılıyorum-3 puan" “Kısmen katılıyorum-2 puan" ve "Katılmıyorum-1 puan” olarak sıralanmıştır.

Taslak form, alan yazın ve uzman görüşleri doğrultusunda çocuğa yönelik şiddetin tanımı, şiddetin normalleştirilmesi, şiddetin kabulü, nedeni, sonuçları ve önlenmesi konularını kapsamıştır. Şiddetin kabulüne ilişkin maddeler ters puanlanmıştır. Alınan yüksek puanın, katılımcıların çocuğa yönelik şiddete duyarlıklarının da yüksek olduğunun göstergesi olarak ele alınması uygun görülmüştür. Hazırlanan form, Çocuğa Yönelik Şiddete Duyarlık Ölçeği (ÇOYŞDÖ) olarak isimlendirilmiştir.

-Ön uygulama aşamasında; taslak form, araştırma evreninden basit rasgele yöntemle belirlenen 6 kadın ve 14 erkek olmak üzere 20 kişiye uygulanmıştır. Bu ön uygulama sonunda, katılımcılara maddelerle ilgili görüşleri ve önerileriyle katkı sağlayabilecekleri belirtilmişir. Ön uygulama sonrasında, düzeltme sonrası hedef grup tarafından anlaşılamadığı düşünülen iki madde ölçekten çıkarılmıştır. Ölçekte kalması uygun görülen 31 madde, rastlantısal olarak karışık şekilde sıralanmış ve ölçek, geçerlik ve güvenirlik çalışması için hazır hale gelmiştir.

-Deneme uygulaması aşamasında; ölçeğin uygulanabileceği örneklem sayısının belirlenmesinde, en az gözlenen değişken sayısının beş katı olması gerektiği dikkate alınmış, değişken (madde) oranının 10:1 olması (Şahin ve Dişsiz, 2009: 267) planlanmıştır. Çalışmaya katılmaya gönüllü olan Karabük ve Bartın Üniversitelerinde lisans düzeyinde öğrenim gören 210 üniversite öğrencisine ölçek uygulanmış, geçerli 202 veri değerlendirmeye alınmıştır.

-Yapı geçerliğinin belirlenmesi aşamasında; faktör analizinden yararlanılmıştır. Ölçeğin 31 maddelik yapısının geçerliğini belirlemek amacıyla Açımlayıcı Faktör Analizi (AFA) yapılmıştır. Ayrıca ölçeğin yapı geçerliği, özellikleri bilinen grupların karşılaştırılması yoluyla da incelenmiştir. Yapılan Kolmogorov Smirnov analizi sonucunda ÇOYŞDÖ puanlarının cinsiyete göre anlamlı farklılık gösterip göstermediği Mann Whitney U-Testi, yaşa göre anlamlı farklılık gösterip göstermediği tek yönlü varyans analizi (ANOVA) ile incelenmiştir.

-Ölçeğin güvenirliğinin belirlenmesinde; Cronbach Alpha Katsayısından yararlanılmıştır (Büyüköztürk, 2002). Anlamlılık düzeyi olarak 0,05 belirlenmiştir.

\section{BULGULAR ve YORUM}

Ölçeğin yapı geçerliğini istatistiksel olarak tespit etmek için yapılan AFA öncesi, faktör analizine uygun olup olmadığını anlamak amacıyla KMO ve Bartlett testi yapılmıştır. Bu kapsamda KMO testi ölçüm sonucunun 0,60 ve daha üstü, Bartlett 
küresellik testi sonucunun da istatistiksel olarak manidar olması gerekmektedir (Jeong, 2004: 70). Bu çalışma sonucunda KMO testi sonucu 0,75 bulunurken, Bartlett küresellik testi de $(\mathrm{p}<0,01)$ manidar bulunmuştur. Buna göre, değişkenler arasında yüksek korelasyonların mevcut olduğu, yani veri setinin faktör analizi için uygun olduğu görülmüştür (Kalaycı, 2009). Ölçeğe faktör analizi yapılabileceği sonucuna ulaşılmıştır. İlk analizde, öz değeri 1'den büyük olan 10 faktör olduğu belirlenmiştir. Ancak Grafik 1 incelendiğinde, öz değeri diğer faktörlerden daha yüksek olan ve açıkladığı varyansı daha yüksek olan tek faktörün baskın olduğu anlaşılmaktadır. Faktörlerin öz değerlerine ait saçılma diyagramı Grafik 1'de verilmiştir.

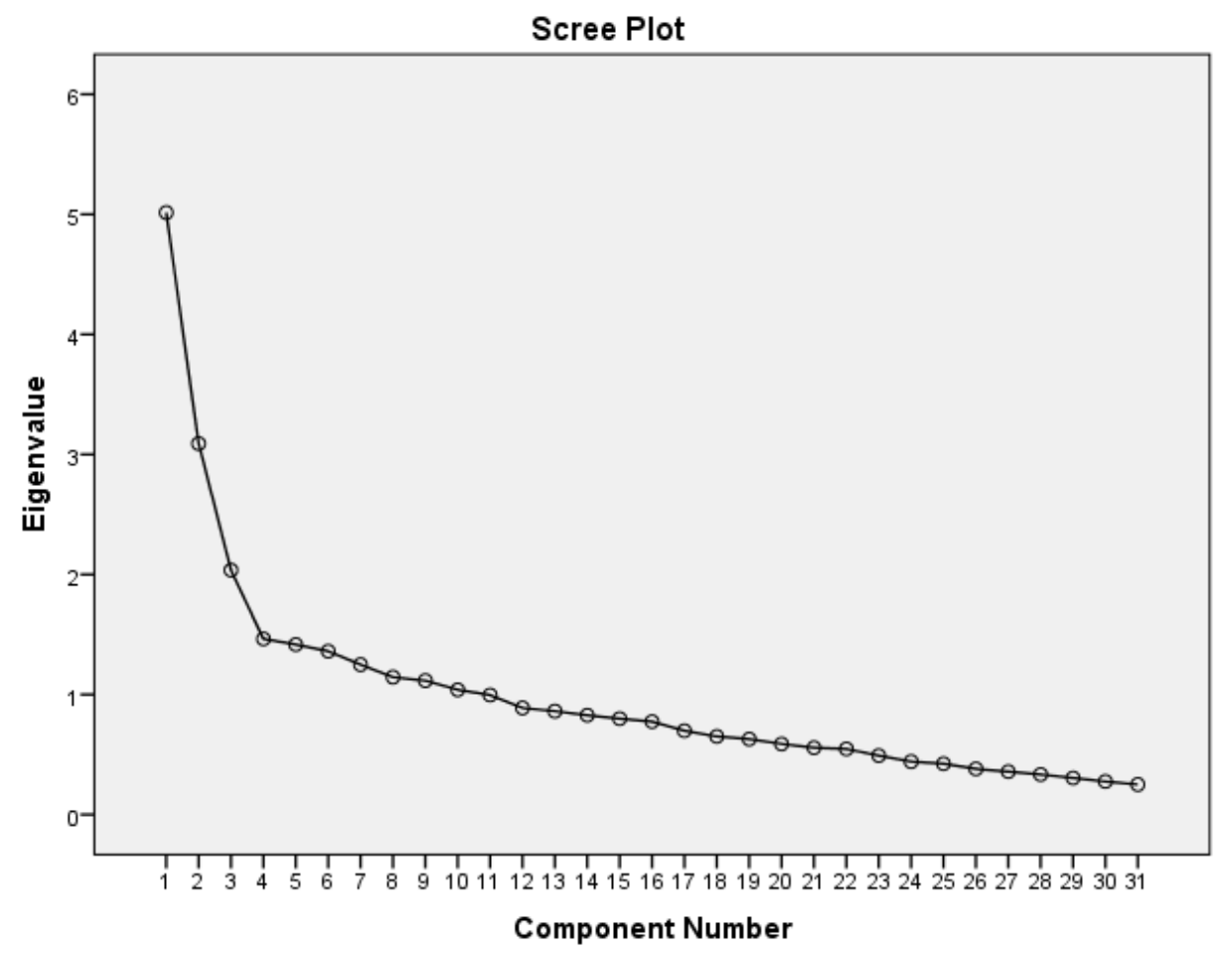

Grafik 1. Faktörlerin Öz Değerine Ait Saçılma Diyagramı

Ölçeğin tek faktörlü bir yapı sergilediği belirlendikten sonra faktör analizi tekrar edilmiştir. Tek faktörlü yapıda maddelerin yer aldığ1 faktördeki yük değerleri için sınır değer 0,30 olarak alınmıştır. Faktör yük değeri 0,30'un altında olan maddeler, binişik ve birbirine yakın değere sahip maddeler sırasıyla çıkarılarak AFA tekrarlanmıştır. verilmiştir.

Nihai analiz sonunda, AFA ile elde edilen faktör yük değerleri Tablo 1'de 
Tablo 1. Ölçeğe Ait AFA Sonucu Faktör Yük Değerleri

\begin{tabular}{lllc}
\hline Madde & Faktör- 1 & Madde & Faktör-1 \\
\hline M28 & 0,735 & M4 & 0,427 \\
M23 & 0,696 & M17 & 0,401 \\
M27 & 0,669 & M15 & 0,394 \\
M31 & 0,623 & M10 & 0,388 \\
M26 & 0,621 & M19 & 0,379 \\
M30 & 0,570 & M21 & 0,369 \\
M29 & 0,507 & M24 & 0,359 \\
M25 & 0,468 & M20 & 0,351 \\
M7 & 0,457 & M9 & 0,327 \\
M18 & 0,434 & & \\
\hline
\end{tabular}

Tablo 1'e göre, ölçeğin tek faktörlü olduğu ve toplam varyansın \%24,92'sini açıkladığ 1 sonucuna ulaşılmıştır.. Yapılan faktör analizi sonucunda elde edilen veriler, ölçeğin geçerliğinin yeterli düzeyde olduğuna işaret etmektedir.

Tablo 2'de ÇOYŞDÖ puanlarının cinsiyete göre Mann Whitney U-Testi sonuçları verilmiştir.

Tablo 2. ÇOYŞDÖ Puanlarının Cinsiyete Göre Mann Whitney U-Testi Sonuçları

\begin{tabular}{lccccc}
\hline \multicolumn{1}{c}{ Cinsiyet } & N & $\overline{\mathbf{X}}$ & Ss & Z & p \\
\hline Kadın & 101 & 47,09 & 6,13 & $-4,173$ & $0,000^{*}$ \\
Erkek & 101 & 43,07 & 8,72 & & \\
Toplam & 202 & 45,08 & 7,78 & & \\
\hline
\end{tabular}

${ }^{*} \mathrm{p}<0,001$

Tablo 2' de, ÇOYDŞÖ' den elde edilen puanların, cinsiyete göre manidar farklılık gösterdiği $(\mathrm{p}<0,05)$; kadınların puan ortalamalarının $(\overline{\mathrm{X}}=47,09)$ erkeklerin puan ortalamalarından $(\bar{X}=43,07)$ manidar düzeyde yüksek olduğu görülmektedir. Buna göre; kadınların çocuğa yönelik şiddete duyarlıklarının erkeklerden daha yüksek olduğu söylenebilir. Türkiye'de ve Dünya'nın birçok ülkesinde kadına yönelik şiddet konusunda ciddi olayların meydana gelmesi (Fernandez Alvarez ve Kouadio Alexis, 2014: 9) kadınların konuya daha hassasiyetle yaklaşmalarında etkili olabilir. Şiddet, en yaygın şekliyle kocanın kadına uyguladığı ve ebeveynlerin çocuklarına yönelttikleri şiddet olarak görülmektedir. Aile bireylerine ve genelde güçlü olanın güçsüz olana uyguladığı şiddet içerikli eylemler, aile içinde görülen fiziksel, cinsel ve duygusal nitelikteki olumsuz eylemler şiddeti oluşturmaktadır. Genel olarak kocalar eşlerine, anneler çocuklarına şiddet uygulamakta; çocukluğunda hem anne hem de babalarından dayak yiyen erkek çocuklar, eşlerine şiddet uygulamakta ve bu döngü sürüp gitmektedir (Ayan, 2007: 97). Kadınların çocuğa yönelik şiddete duyarlıklarının daha yüksek olmasının nedeni, doğrudan veya dolaylı olarak şiddet mağduru olmalarından ve konuya hassasiyetlerinden kaynaklanabilir.

Tablo 3'te ÇOYŞDÖ puanlarının katılımcıların yaşına göre tek yönlü varyans analizi (ANOVA) sonuçları verilmiştir. 
Tablo 3. ÇOYŞDÖ Puanlarının Yaşa Göre ANOVA Sonuçları

\begin{tabular}{lccccc}
\hline \multicolumn{1}{c}{ Yaş } & $\mathbf{N}$ & $\overline{\mathbf{X}}$ & Ss & $\mathbf{F}$ & $\mathbf{p}$ \\
\hline 20 yaş ve altı & 28 & 47,14 & 5,97 & 1,589 & 0,207 \\
21-25 yaş & 158 & 44,93 & 7,79 & & \\
26 yaş ve üstü & 16 & 43,00 & 9,94 & & \\
Toplam & 202 & 45,08 & 7,78 & & \\
\hline
\end{tabular}

Tablo 3'e göre, ÇOYŞDÖ alt boyut puanlarında katılımcıların yaşına göre manidar bir fark yoktur $(p>0,05)$. Buna göre, katılımcıların çocuğa yönelik şiddet algılarının yaşlarından manidar düzeyde etkilenmediği söylenebilir.

Ölçeğin güvenirliğinin belirlenmesinde kullanılan iç tutarlılık katsayısı olan Cronbach Alpha değeri, tek faktörlü yapı için 0,82 olarak belirlenmiştir. Tezbaşaran (1997), likert tipi bir ölçekte yeterli sayılabilecek bir güvenirlik katsayısının olabildiğince 1'e yakın olması gerektiğini ifade etmektedir. Buna göre, ölçeğin güvenirliğinin yüksek düzeyde olduğu söylenebilir.

\section{SONUÇ ve ÖNERİLER}

Yetişkinlerin çocuğa yönelik şiddete duyarlıklarını belirlemede yararlanılabilecek bir ölçek geliştirilmesi amaçlanan bu çalışmada, ölçek geliştirme basamakları izlenerek madde havuzu oluşturma, uzman görüşü alma, ön deneme uygulaması ve geçerlik güvenirlik çalışmaları yapılmıştır. Geliştirilen "Çocuğa Yönelik Şiddete Duyarlık Ölçeği (ÇOYŞDÖ)” geçerlik ve güvenirliğinin incelenmesi sonucunda, ölçeğin 19 maddelik tek boyuttan oluştuğu belirlenmiştir. Ölçeğin ölçüt geçerliği cinsiyet ve yaş dış ölçütüne göre analiz edilmiş, çocuğa yönelik şiddete duyarlığın cinsiyet değişkeninden anlamlı ölçüde etkilendiği, yaş değişkeninden etkilenmediği belirlenmiştir. Ölçeğin güvenirliğini belirlemek amacıyla bakılan Cronbach Alpha iç tutarlık katsayısı, ölçeğin tümü için 0,82 olarak hesaplanmıştır. ÇOYŞDÖ'nin geçerliğinin ve güvenirliğinin ölçeğin geneli için yüksek olduğu, yetişkinlerin çocuğa yönelik şiddete duyarlıklarını ayırt edebileceği ve konuyla ilgili araştırmalarda kullanabileceği düşünülmektedir.

Yapılacak gelecek çalışmalarda, örneklem grubuna göre güvenirlik katsayılarının hesaplaması ölçekle ilgili verilere katkı sağlayacaktır. Çocuğa yönelik şiddet uygulayan bireylerin, çocukla ilgili alan çalışanı olarak eğitimcilerin, sağlık çalışanlarının, her şeyden önce de anne ve babaların çocuğa yönelik şiddete duyarlıklarının belirlenmesi çalışmalar yapılabilir. Farklı çalışma gruplarıyla yapılacak çalışmalar çocuğa yönelik şiddeti önlemeye ilişkin çalışmalara ışık tutacaktır.

\section{KAYNAKÇA}

Akın, A., Gülşen, M., Aşut, S. ve Akça, M. (2012). Yakın ilişkilerde şiddet sorumluluğu ölçeği Türkçe formunun geçerlik ve güvenirliği. Abant İzzet Baysal Üniversitesi Ĕ̆itim Fakültesi Dergisi, 12 (2), 175-184.

Alkan, H. B. (2007). Ilköğgretim öğretmenlerinin istenmeyen davranışlarla baş etme yöntemleri ve okulda şiddet, Yayınlanmamış yüksek Lisans tezi, Niğde: Niğde Üniversitesi Sosyal Bilimler Enstitüsü. 
Ayan, S. (2007). Aile içinde çocuğa yönelik şiddet (Sivaş ilköğretim ikinci kademe öğrencileri üzerine bir inceleme), Yayınlanmamış doktora tezi, Sivas: Cumhuriyet Üniversitesi Sosyal Bilimler Enstitüsü.

Aydoğan, Y. ve Özyürek, A. (2013). Okul öncesi dönem çocuklarda şiddet davranışları, Uluslararası Hakemli Aile Çocuk ve Eğitim Dergisi, 1 (2), 1-18.

Başbakanlık Aile Araştırma Kurumu. (1998). Aile içinde ve toplumsal alanda şiddet, Ankara: T.C. Başbakanlık Aile Araştırma Kurumu Başkanlığı Yayınları Bilim Serisi. No: 113.

Battaloğlu-İnanç, B., Çiftçi, S. ve Değer, V. (2013). Mardin ili ilköğretim okulu öğrencilerinin fiziksel şiddete maruziyetleri ve yaklaşımları, Türk Pediatri Arşivi Dergisi, 221-234.

Büyüköztürk, Ş. (2002). Sosyal bilimler için veri analizi el kitabı. Ankara: Pegem A Yayıncılık

Can, Y. (2007). Illköğretim okullarında şiddet (Öğrenci, öğretmen ve yöneticilerin yaklaşımlarl), Yayınlanmamış yüksek lisans tezi. İstanbul: Beykent Üniversitesi Sosyal Bilimler Enstitüsü.

Çetinkaya Yıldız, E. ve Hatipoğlu Sümer, Z. (2010). Okul öncesi çocuklar ve şiddet: Tanık ve kurban olma düzeyleri, Illköğretim Online, 9 (2), 630-642.

Çobanoğlu, F., Şentürk, İ. ve Kıran, D. (2008). Liselerde yaşanan şiddet olaylarının nedenleri ve çözüm önerileri (Denizli ili örneği). Pamukkale Üniversitesi Eğitim Fakültesi Dergisi, 2 (24), 127-139.

Deveci, H., Karadağ, R. ve Yılmaz, F. (2008). İlköğretim öğrencilerinin şiddet algıları, Elektronik Sosyal Bilimler Dergisi, 7 (24), 351-368.

Devries, K. M., Naker, D., Monteath-van Dok, A., Milligan, C. ve Shirley, A. (2016). Collectingdata on violenceagainstchildrenandyoungpeople: needfor a universalstandard, IntHealth. 8, 159-161.

EARGED. (2008). Öğrencilerin şiddet algısı, Ankara: Millı̂ Eğitim Bakanlığı Araştırma ve Geliştirme Dairesi Başkanlığı.

Ekşi, H., Erkilet, A., Otrar, M., Durmuş, A., Erdoğan, A., Kılınç, C., ... Gökçek, Y. Z. (2010). Medya profesyonellerinin ve medyanın aile algısı. Ankara: ASAGEM.

Elmalı, F., Kaya Erten, Z., Zincir, H., Özen, B. ve Balcı, E. (2011). hemşire ve ebelerin aile içi fiziksel şiddete bakış açıları maruziyetleri, Sağlık Bilimleri Dergisi (Journal of HealthSciences), 20 (1), 39-47.

Fernandez Alvarez, O. ve Kouadio Alexis, L. (2014). Violence against Women and Children. A Distant and Domestic Hell. Procedia Social and Behavioral Sciences, 161, 7-11.

http://www.tdk.gov.tr/index.php?option=com_bilimsanat\&arama=kelime\&guid=TDK.GTS.588b 17f5d01427.92768664.

http://www.tdk.gov.tr/index.php?option=com_gts\&arama=gts\&guid=TDK.GTS.590c67f35baf26. 54622709

Işık, R. ve Sakallı-Uğurlu, N. (2009). Namusa ve namus adına kadına uygulanan şiddete ilişkin tutumlar ölçeklerinin öğrenci örneklemiyle geliştirilmesi. Türk Psikoloji Yazıları, 12 (24), 16-24.

Kline, R. B. (2005). Principles and Practice of Structural Equation Modeling (2nd Edition ed.). New York: The Guilford Press. 
Koştu, N. ve Toraman, A. U. (2016). Sağlık çalışanlarının kadına yönelik eş şiddeti bildirimi yapma niyeti/davranışı ölçeği geçerlik ve güvenilirlik çalışması. Anadolu Hemşirelik ve Sağllk Bilimleri Dergisi, 19 (1), 49-57.

Kurnaz, A. ve Kapçı, E. G. (2013). Saldırganlık ve mağduriyet ölçeklerinin ilköğretim ikinci kademe çocuklarına uyarlanması. Bilişsel Davranış̧̧ı Psikoterapi ve Araştırmalar Dergisi, 2 (2), 106-115.

Ogelman, H. G., Körükçü, Ö., Sarıkaya, H. E., Güngör, H. ve Ersan, C. (2015). Ladd ve profilet çocuk davranış ölçeği, akran şiddetine maruz kalma ölçeği ve resimli sosyometri ölçeği'nin dört yaş Türk çocukları için geçerlik güvenirlik çalışmaları. Afyon Kocatepe Üniversitesi Sosyal Bilimler Dergisi, 17(2), 109-129.

Özaltın, G. (2001). Aile içi şiddetin önlenmesinde ruh sağlının korunmasında aileye yönelik hizmetlerin önemi, T. C. Başbakanlı Aile Araştırma Kurumu 1.Ulusal Aile Hizmetleri Sempozyumu (2000'li Yillarda Aile Hizmetleri), Hacettepe Üniversitesi Aile Hizmetleri Uygulama ve Araştırma Merkezi Bilim Serisi, ss. 108-114. 09-11 Mayı/Ankara.

Savaş, N., İnandı, T., Peker, E. ve Alışkın, Ö. (2015). Ortaokul öğretmenlerinin okullarda şiddeti önlemede öne çıkan tutum ve davranışları: Türkiyeden bir ölçek geliştirme çalışması. TAF Preventive Medicine Bulletin, 14 (3), 247-256.

Sever, M. ve Cinoğlu, H. (2010). Amerikan polisinde iş stresinden kaynaklanan aile içi şiddet olaylarının sosyolojik ve istatistiksel analizi, Polis Bilimleri Dergisi, 12 (1), 125-146.

Sezer, Ö. (2008). Çiftler arası şiddeti kabul ölçeğinin Türkçeye uyarlanması: Geçerlik ve güvenirlik çalışmaları, İnönü Üniversitesi Eğitim Fakültesi Dergisi, 9 (16), 1-15.

Sümer, N. (2000). Yapısal eşitlik modelleri: Temel kavramlar ve örnek uygulamalar. Türk Psikoloji Yazıları, 3 (6), 49-74.

Şahin, N. ve Dişsiz, M. (2009). Sağlık çalışanlarında aile içi şiddete yönelik tutum ölçeği geliştirme çalışması, Uluslararası İnsan Bilimleri Dergisi, 6 (2), 263-

Şenol, D. ve Yıldız, S. (2013). Kadına yönelik şiddet algısı-kadın ve erkek bakış açılarıyla-, Ankara: Mutlu Çocuklar Derneği Yayınları.

Tezbaşaran, A. (1997). Likert tipi ölçek geliştirme kılavuzu. (İkinci baskı), Ankara: Türk Psikologlar Derneği Yayını.

Tezel Şahin, F. ve Özyürek, A. Üniversite öğrencilerinin aile içi şiddete yönelik görüşleri, Akademik Bakış Uluslararası Hakemli Sosyal Bilimler E-Dergisi, 40: 1-18.

Tunay, Ş. ve Soygüt, G. (2009). Türk üniversite öğrencileri üzerinde Endişe Şiddet Ölçeği'nin güvenirlik ve geçerliği. Türk Psikiyatri Dergisi, 20 (1), 68-74.

Tuz, C., Öksüz, M. E. ve Tekiner, S. A. (2015). Kadına yönelik şiddet derecelendirme ölçeği ve mağdurların cinsel deneyimleri ölçeği Türkçe versiyonunun geçerlilik ve güvenilirliği. EurasianJournal of FamilyMedicine, 4 (2), 83-89.

Volavka, J. (1999). Theneurobiology of violence: An update, J Neuropsychiatry Clin Neurosci, 11 (3), 307-315.

Yaman, E. (2009). Psikoşiddet (mobbing) ölçeği: Geçerlik ve güvenirlik çalışması. Kuram ve Uygulamada Ĕ̆itim Bilimleri, 9 (2), 967-988. 
A. Özyürek / Karabük Üniversitesi Sosyal Bilimler Enstitüsü Dergisi, 2017, 7 (2), 462-472

Yaman, E. (2012). Psikoşiddetin (Mobbing) etkileri ölçeği. Kuram ve Uygulamada Eğitim Bilimleri, $12(1), 231-240$.

Yumuşak, A. ve Şahin, R. (2014). Flörtte şiddete yönelik tutum ölçeklerinin güvenirlik ve geçerlik çalışması, Elektronik Sosyal Bilimler Dergisi, 13 (49), 233-252. 


\section{Ek: Çocuğa Yönelik Şiddete Duyarlık Ölçeği ve Puanlaması}

\begin{tabular}{|c|c|c|c|}
\hline İfadeler & 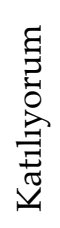 & 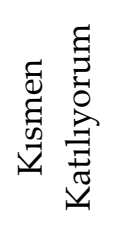 & 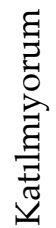 \\
\hline $\begin{array}{l}\text { 1. Çocuğun şiddete tanı olmasını önlemek, gelecekte şiddet } \\
\text { uygulayan bir birey olmasını önleyebilir. }\end{array}$ & 3 & 2 & 1 \\
\hline $\begin{array}{l}\text { 2. Şiddet gören çocuklar, başkalarına şiddet uygulama eğilimi } \\
\text { gösterirler. }\end{array}$ & 3 & 2 & 1 \\
\hline $\begin{array}{l}\text { 3. Şiddet uygulayan anne-baba veya yetişkin, çocuğa kendini } \\
\text { affettirirse sorun kalmaz. }\end{array}$ & 1 & 2 & 3 \\
\hline $\begin{array}{l}\text { 4. Şiddet, çocukla olumsuz duygulanıma sebep olacak şekilde } \\
\text { konușmaktır. }\end{array}$ & 3 & 2 & 1 \\
\hline $\begin{array}{l}\text { 5. Şiddet, çocuğun duygusal yönden kötü hissedeceği davranışlarda } \\
\text { bulunmaktır. }\end{array}$ & 3 & 2 & 1 \\
\hline $\begin{array}{l}\text { 6. Yetişkinlerin çocuğa şiddet uygulamasının mutlaka geçerli bir } \\
\text { nedeni vardır. }\end{array}$ & 1 & 2 & 3 \\
\hline $\begin{array}{l}\text { 7. Şiddet gören çocuklar, anne-baba olduklarında çocuklarına şiddet } \\
\text { uygulama eğilimi gösterirler. }\end{array}$ & 3 & 2 & 1 \\
\hline $\begin{array}{l}\text { 8. Ailenin sosyo-kültürel ortamının iyileştirilmesi, çocuğa yönelik } \\
\text { şiddeti önleyebilir. }\end{array}$ & 3 & 2 & 1 \\
\hline $\begin{array}{l}\text { 9. Şiddet gören çocuklar, çevresindekiler tarafından istenmeyen } \\
\text { davranışlar sergilerler. }\end{array}$ & 3 & 2 & 1 \\
\hline $\begin{array}{l}\text { 10. Düşük sosyo-ekonomik ve kültürel düzeyde aileye sahip çocuklar, } \\
\text { daha fazla oranda şiddet görürler. }\end{array}$ & 3 & 2 & 1 \\
\hline 11. Şiddet gören çocuklarda, kin ve düşmanlık hisleri oluşur. & 3 & 2 & 1 \\
\hline $\begin{array}{l}\text { 12. Büyükanne ve büyükbabaların çocuğa şiddet uygulamasına, diğer } \\
\text { aile bireylerinin müdahale etmemesi gerekir. }\end{array}$ & 1 & 2 & 3 \\
\hline $\begin{array}{l}\text { 13. Yasal yaptırımların artırılması, çocuğa yönelik şiddet olaylarını } \\
\text { engelleyebilir. }\end{array}$ & 3 & 2 & 1 \\
\hline 14. Yaramazlık yapan çocuklar, şiddet görmeyi hak etmişlerdir. & 1 & 2 & 3 \\
\hline $\begin{array}{l}\text { 15. Yetişkinlerin çocuk gelişimi konusunda eğitimi, çocuğa yönelik } \\
\text { şiddeti önleyebilir. }\end{array}$ & 3 & 2 & 1 \\
\hline $\begin{array}{l}\text { 16. Toplumun duyarlığını artırıcı etkinlikler, çocuğa yönelik şiddeti } \\
\text { engelleyebilir. }\end{array}$ & 3 & 2 & 1 \\
\hline 17. Şiddet, çocuğu ilgi ve sevgiden yoksun bırakmaktır. & 3 & 2 & 1 \\
\hline 18. Bir çocuk şiddet gördüğünü söylüyorsa, inanmamak gerekir. & 1 & 2 & 3 \\
\hline 19. Şiddet gören çocukların gelişimleri olumsuz etkilenir. & 3 & 2 & 1 \\
\hline
\end{tabular}

